\title{
Assessment Of Human Resource Variables As Correlates of Students' Performance In Mathematics In Secondary Schools
}

\author{
Patrick U. Osadebe (Ph.D) \\ Department Of Guidance And Counselling \\ Delta State University Abraka, Nigeria \\ Tebekaemi Omonibo Ebikoro \\ Delta State University Abraka, Nigeria
}

\begin{abstract}
This study focused on the Assessment of Human Resource Variables as correlates of students' performance in Mathematics in Secondary Schools in Delta South Senatorial District. The study investigated the relationship between human resource variables and students' academic performance in Mathematics in Senior Secondary schools. To achieve this purpose, seven research questions and seven hypotheses were raised to guide the study. The theoretical and empirical findings related to the study were reviewed. It was an ex-post facto study with a population of 2,721 . A sample of 870 teachers of Senior Secondary Schools were selected through proportionate stratified random sampling techniques from forty Senior Secondary Schools within Delta South Senatorial District. Face and content validity of the instrument used was established. The reliability of the study was determined by the test-retest method and obtained the reliability coefficients 0.72 . The scores obtained were analyzed using coefficient of determination and regression method of data analysis. The hypotheses were tested at 0.05 level of significance. Four of the null hypotheses were rejected while three were accepted. The results indicated that staff qualification, teaching experience, specialization of teachers is related to students' academic performance in mathematics. However, there were no significant relationship between sex, age of teachers and marital status of teachers on students academic performance in Mathematics. From the findings, the study generally recommends that more qualified and professional hands should be encouraged to engage in teaching of mathematics in order to avert the perennial dismal performance of students.
\end{abstract}

Keywords: Assessment, Human Resource Variables, Performance, Mathematics

\section{INTRODUCTION}

Over the years, educational institutions have developed into a complex and functional field of endeavour from the past experiences. Changes in the political, social, technological, economic, religious and scientific areas have contributed immensely to the development of educational institutions. Therefore, for educational institutions to survive in relation to this rapidly changing environment, there must be change with it, adjust and adapt to the new technologies and new methods of doing things. All these pose many problems and difficulties. Consequently, available physical and human resources have become imperative to achieve the overall goals and objectives of the school organization.

Technological advancement for example has resulted into the use of new methods of teaching, while government intervention in education has brought about constant changes in educational policies. We also have changing expectations of workforce, demand for more pay and benefits but less work and dedication along with the deteriorating infrastructure in our 
Schools. These and many other changes have created problems which available human resources have to cope with and meet the set goals and objectives of the School system.

According to Nwagwu (2005), students may have different backgrounds and divergent individual interest and characteristics, individuals coming into the organization presupposes their belief and hope that the organization will help them to attain their individual objectives and collective aim of the existence of the organization, and for this premise to happen, there must be availability of material and human resources in the organization,.

One of the basic aims of school organization is high academic performance by the students but this has constantly been a problem in senior secondary schools in the South Senatorial district in Delta State especially in Mathematics. Many students find Mathematics lessons boring as many Mathematics teachers lack the understanding and practical skill of scientific processes, most Mathematics classes are so designed that students go through restrictive instructions without being able to identify the practical problems and select various methods and materials where it become necessary leading to poor academic performance. The academic performance of students in some schools can be affected by a number of factors. These factors could be the academic qualification of teachers, teaching experience of the teachers, gender of the teacher, marital status of teachers, Age of teacher and specialization of teachers. Apart from these factors other variables include poor cultural influence, level of parent education, student attitude towards learning and among others. However, for the purpose of this study, emphasis will be based on academic qualification of teachers, teaching experience of teachers, marital status of teachers, Age of teacher, Area of specialization and gender of the teachers on the academic performance of students in mathematics at senior secondary school (SSS) level.

The gender (sex) of a teacher and student have greater influence on the academic performance. Mathematics has been viewed by the public as subject meant for more of the boys than girls. They have supported it that males have a learning edge over the females. Hence males are regarded as the dominant and even "superior" sex readily believed without of course any empirical support that they (males) intrinsically have better brains and learn much better than females.

Successive governments in Nigeria both State and Federal have made frantic efforts towards the provision of enough materials and human resources in educational institutions. Despite these efforts, certain challenges continue to emanate in the areas of poor qualification of staff, location of Schools, Gender differences, marital status of teachers, Age of teacher, area of specialization and teaching experience of teachers and dedication and devotion of teachers to duties. Sequel to the deterioration in students' performance in Mathematics in promotion Examination in SS2 year in year out has necessitated this study.

To adequately handle the forgoing challenges, concerted efforts have to be made towards the provision of qualified staff and infrastructure in secondary schools, which involves determining and ensuring that the schools have adequate number of qualified and experienced staff available at the proper time, infrastructure, performing jobs which meet the needs of the school and provide satisfaction for the individuals involved. The availability of physical and human resources in the school system is to bring about high standards in school achievements, high academic performance, reduction in dropout rate, appropriate staffing and fair class size.

According to Arikewuyo (1999), the type of staff training provided for its workers in an organization contributed immensely to productivity. Ajayi (1987) observed that our educational programme started crashing from the days of crash programmes. Teachers were 
rushed through these crash programmes to obtain National Certificate of Education (NCE). Poor training produced poor teachers and poor teachers in turn produce poor students. The main objective of qualified teachers is to increase productivity and ensure high standard of students' academic performance.

Class size, according to Ehiametalor (1985), inhibits the level of learning activities and prevents class interaction. This is sequel to the fact that where there are about 100-140 students per class, due to lack of adequate classroom in the School; some students would have to stand outside or sit on the windows to listen to lessons. In such a situation, large proportion of the students do not see or hear the teacher very well. This seriously affect academic performance in such Schools.

Mannheim and Steward (1962) acknowledged that three main factors contribute to the backwardness in School performance. These factors according to them are environmental, intellectual and emotional. Environmental factors as identified by them include crowded classes, poorly equipped facilities and under staffed schools. They emphasized that these result to low academic performance.

Anukam (2001) found that in the enormous task of achieving goals in the primary school, the school head comes in contact with three key human resources factors namely teachers, pupils and parents. Each of these partners, in his or her interaction with the school heads brings some challenges that could jeopardize the pupils' performance if ignored. Availability of enough human resources can inspire or influence the attitudes, the activities of the school so that the group members can work co-operatively towards realization of set goals.

In the proceeding paragraphs, the importance of human and material resources has been stated without knowing their relationship with the academic performance of students in senior secondary schools, high academic performance is one of the objectives of secondary school education in Nigeria. State and Federal Governments do invest on secondary schools. And when such investments are made in secondary schools, all the stakeholders want to know the contributions to the academic achievement of the students. This is because in Nigeria, when a Secondary School does well in the senior School Certificate Examination (SSCE), it is highly applauded by the community. For a Secondary School to do well in the public Examinations, qualified teachers be recruited into the School, good buildings be erected, facilities and equipments be procured to enhance teaching and learning while other variables that could influence students' academic performance include experienced staff, staff evaluation, guidance and counseling services and so on. The independent variables of the study include staff qualifications, staff experience, marital status of teachers, Age of teacher specialization of teachers and gender difference. While the dependant variable is student performance.

It is the belief of people that when School certificate Examination results are good, teachers indeed the final class (SSS III) teachers do neglect all others who had contributed to the success of these students throughout their stay in the School. What is being said is that it may not be the contribution of only a single variable that leads to excellence, very good or very poor academic performance in Secondary School final year Examination. Therefore, it is important to investigate the correlation of each of these human resource variables to the students' performance in Mathematics as earlier stated.

\section{LITERATURE REVIEW}

Theoretical and Empirical findings related to the study were reviewed. The literature was reviewed under subheadings in line with the research questions and hypotheses. 


\section{Staff Qualification}

Human resources are the driving force of any organization. Becker and Gerhart (1996) said no industry can be rendered efficient so long as the basic fact remains unrecognized that is principally human. Teachers are the driving force in the wheel of educational process in any society. Their role within the educational system is multi-dimensional. In the light of this, Odunsi (2000) noted that no matter how grandiose a school system and its programmes are, the overall academic performance will be fruitless unless they are handled by competent and adequately qualified teachers. Therefore, the ultimate realization of the aims of education and thus the achievement of the country's need depends on the quality of teachers in schools. Teachers are a force to reckon with for school to achieve its objectives.

Hallack (1990) emphasized that the quality of an educational system depends on the quality of its teachers. The National Policy on Education (NPE) by the Federal Government of Nigeria (2004), in aligning with Hallack (1990) stated that no educational system can rise above the quality of its teachers. Fagbamiye (1987) also remarked that teachers competence contribute to students' academic achievement.

Tamir (1979) and Gehbauer (1979) in their studies, found that teachers' educational background and experience have significant effect on teaching and students' academic performance. The works of Boomls (1969) and Levin (1970) indicate that teachers' qualifications have strong influence on students' academic performance

Similarly, Akande (1999) liken teachers to the principal factory operator. The quality of the school product is largely a function of the qualities of the teachers. If the school system had adequately qualified teachers they will produce students with high academic performance skills knowledge and so on.

According to Hammond (1997) and Evertson (1984) in reviews of past research works over 30 years concluded in their summary that adequately qualified and certified teachers are better rated and more successful with students than teachers without adequate qualification. They explained that such teachers without adequate qualification have difficulties in meeting the needs of the students. Price (1996) and Heinshel (1998) in their various studies and subsequent findings agree that the training which a teacher received prove to be important in students' academic performance.

Recent research by Wenghinsky (2002) on the link between teacher qualification and students' performance, found out that teachers input do influence students' academic performance. Wenghinsky notes that the greatest influence on students' academic achievement comes from the classroom practices and professional development that supports them. Wenghinsky's research indicates that regardless of the level of preparation students bring into the classroom, teacher's decision made about the subject matter can either facilitate students learning or serve as an obstacle to learning. Thus an inadequately qualified teacher will produce students with low academic performance.

Azango (1972) has opined that give bright students with modern facilities and large budget but poor quality teachers, the quality of instruction provided is bound to be poor and consequently, the product which is sent into the labour market to hold middle and high level jobs is compelled to be unproductive, inefficient and ineffective because the basic skills are deficient. Thus a crop of unqualified teaching staff are likely to produce poor students with low academic achievement. 
In the third National Development Plan (1975 - 80) failure to provide suitable and qualified teaching staff in terms of number and quality was identified as one of the major problems facing educational sector. The objective of the then Government was therefore expressed as stepping up the training of teachers at higher levels up to NCE standard in view of gross inadequacy of qualified teachers for Secondary School system. From the above, it would appear that any school with unqualified teachers will result poor academic performance with consequent retardation in the flow of students through the school circle.

Aghenta (1981) is of the view that people have started to distinguish between education and high quality education. They have also begun to know that high quality teachers are no longer born but also made. He further added that this type of teachers have innate abilities. Professional training is important, though many people still have the notion of born teacher. Indeed high academic achievement can only be realized through trained and qualified teachers. It is what you put in, that you get out. He also noted that training generally leads to improvement of skills and confidence through adaptability and new insights, new orientation, better organization which ultimately is passed to students to produce high academic achievement.

Nwagwu (1984) attributed the falling standard in academic performance or education to the presence of auxiliary teachers. He said that there is abundant evidence to conclude that poorly trained and unqualified teachers are responsible for the low educational standard in our schools.

Abubakar (1978) sees teacher's qualification as being very important in determining the educational standard (academic performance) of all students in all stages and at different levels of educational institution. He noted that the falling standard of education may be attributed to a number of factors among which is shortage of qualified teachers.

Obiolor (1973) attributed falling standard of education (academic performance) in Nigeria to employment of non-professionally qualified teachers or staff who use teaching profession as not only a stepping stone to other professions but also as a dumping ground. The ultimate test of teacher's effectiveness should be its consequence on students.

However, no matter how qualified a teacher may be at the point of entrance, the advancement in science and technology in contemporary world, a teacher needs to update his or her professional knowledge regularly in order to cope with changes in knowledge and the teaching techniques. As rightly remarked by Baron (1978) yesterday good teacher is not automatically today's good teacher. Hence, for a teacher to be adequately prepared at all times he or she has to continuously up-date his or her knowledge in order to be able to discharge his or her duties effectively and efficiently.

Educational qualification and experience of a teacher affects his ability to set behavioural objectives, teach and evaluate a lesson. Fafunwa (1970), Onwuegbu (1970) and Ogbebor (1997) agreed that the quality of training of the teacher will enable him to possess the essential qualities of teaching which include, knowing the subject matter, knowing how to deliver a lesson and knowing the method of getting to know the learner. Awokoya (1981) also opined that the quality of education depends on the quality of teachers training, since they can only teach what they know.

Iyeke (2001), also buttress to the fact that an effective and prolonged training and education harnesses on the teacher superior competence, skills, values and experiences which are 
relevant for the effective performance of the various tasks of teaching. Ezewu and Adejumo (1985) also reported that teacher's qualification and training will enable him to manifest evidence of knowledge of content, intellectual ability, sympathy and understanding of human nature, interest in teaching and the capability to deliver the acquired knowledge to a group of students within the teaching-learning environment.

On this premises, teacher appointment is based on certain qualifications recognized by the NPEsuch as NCE, BA (ED), B.ED, B.Sc (Ed), B.Sc. PGDE, B.A. M.Ed, Ph.D in Education. Holders of these qualifications are considered qualified to teach in any of the Nigerian Secondary Schools. Holders of the NCE have been advised to go and obtain their Bachelor of Education degree. Infact, the NPEhas recommended that the least qualified teacher in the Secondary Schools should be holders of Bachelor of Education degree while the NCE holders should move to the primary School system (Okorodudu 1999).

\section{Gender and Sex}

Gender and sex are two different concepts. Sex can be defined as the biologically determined characteristics of man and woman. On the other hand gender refers to all the characteristics of man and woman which a particular society has determined and assigned as sex. In the same perspective, gender refers to many socially and/or culturally constructed characteristics qualities, behaviour and rules which different societies, ascribe to male and female. Gender stereotype is very much in our modern society. This gender concept, equally permeates the education system especially Mathematics, Science and Technology and almost all spheres of human endeavour (Edhebe, 2004).

Federal Ministry of Education (FME) (1993) noted that national averages for school enrolment and adult literacy rates are generally negatively influenced by gender factor whereby girls' enrolment and female literacy have remained very low. The document identified cultural and economic challenges to female access to education, parental ignorance of benefits of female education, early marriages, teenage pregnancy and economic hardship.

Science teachers Association of Nigeria (1992) revealed that female education in terms of enrolment and achievement are lower than male in areas of science and technology. Williams (1988) pointed out that in the last 100 years, education opportunities in Nigeria were not equally available to boys and girls with a ratio of 1:10 in favour of boys. Fafunwa (1997) also opined that educational opportunities available to the girls were domestic science and marriage preparations. Even the curriculum in the girls' secondary school do not emphasize science subjects. Therefore, the girls who wanted to study pure science had to seek admission into boys' schools after they had obtained full secondary education in their schools. This thus affect student's academic performance in mathematics, in higher level of education sequel to the fact that the foundation is shaky

Oyedokun (2001) observed that the low female enrolment in science subjects in the Mathematics lead to low production of female science teachers to teach junior secondary school and primary school where they are expected to serve as role models for girls to develop interest in Mathematics. Oriafo (1986) is of the opinion that by the special endowment and influence of women as mothers, their interest and participation in science will encourage the development of science and technology in the society.

Balogun (1984), Osibodu (1985) and Williams (1987) affirmed that girls were being discriminated against in terms of educational opportunities. They further stated that girls were being discouraged from taking careers in Mathematics, Engineering and other Science related 
courses. Ogunleye (2000) attributed the low academic performance of girls to lack of role models of women in secondary schools. Ogunleye (2006) also cited the low employment of female in the teaching profession also affect academic performance of student in mathematics in secondary school.

Based on gender issues, Bitoku (2000) suggested that gender sensitivity workshop be organized from time to time as a parameter for encouraging females in participation of science and technology. The Universal Basic Education (UBE) scheme as a tool for education for all should be fully implemented; the present curriculum review should be gender friendly.

In the area of gender, learner and learning of the various biological differences in human makeup such as male and female, people have suspected that one sex may have a learning edge over the other. Men are regarded as the dominant and even "superior" sex people readily believe without of course, any empirical support that the men have better brains intrinsically than women but modern psychological studies have convincingly pointed out that the individual's cultural setting and environment both physical and psychological which impinge on the individual rather than differences in the intelligence make-up of male and female affect learning intrinsically, there is practically no significant difference in the intelligence between a male and a female which can be traceable to sex difference per se (Ezewu, 1984) of course. Gesell (1954) has pointed out that before 11 years plus that is when children are under eleven years of age, girls perform better in Mathematics operations than boys of the same age bracket. Gesell further says that after eleven years, boys usually overtake the girls. But this can be explained in terms of other intervening factors influencing the individuals and their learning capabilities. In other words, the girls alleged better performance in Mathematics could be seen as a function of cultural upbringing of the children. For example, mothers are in firmer control of their daughters before they are eleven years than after they have passed this age. Since girls before the age of eleven years that is at the nursery and primary school levels are closer to their mothers than their male counterparts (boys). The girls are by this fact more exposed to practical mathematics than the boys. This appears a logical way of explaining Gesell's statement that girls are better in Mathematics before eleven years than boys.

Tyler and Herdy (1977) have pointed out that girls do better than boys in classificatory and discriminatory tests which boys are accorded better performance in visual and spatial task. Viewed from the cultural orientation point. It can be argued that girls are part and parcel of their apprenticeship and understanding of their mothers, girls are usually exposed to arranging chairs in the palours according to classified shapes and colour, arranging carpets, window blinds to match the colour of chairs in the palour. All these provide girls the opportunities for much more practical training in performing classificatory and discriminatory task by identifying differences between one thing and the other than boys of this level of age.

Walberg (1989) has pointed out that in verbal and skills, girls outdo boys. However, in the pioneering study carried out by (Maccoby and Jacklin 1974) agreed that girls out performed boys in verbal abilities and that boys had superior qualitative and spatial abilities. This conclusion was accepted as one of the tuitions of the psychological literature.

It may be interesting and enlightening to cite some relevant studies about sex differences in the learning performance of Nigerian children. Ezewu (1980) using Nigerian secondary students found inconsistency of results as regards sex difference in Mathematics and English Language performance. Okoye (1983) in his studies on the same area using primary school pupils found no significant difference in Mathematics and English Language performance of boys and girls. Though it can be argued that whether a boy or a girl performs relatively better would depend 
on the individual boy or girl, given various cultural and environmental contingences which impinge on the boy or girl, gender differences per se is notwithstanding at all.

Boocook (1980) viewed that test scores indicated that on all measures there is considerable overlap between the distribution of scores for male and female and that on tests of total abilities, the gender do not matter significantly. Superior or highly developed ability is more or less equally distributed among boys and girls. Historically, boys participate more than girls in learning activities. They (boys) ask questions and make comments about ideas being discussed in class and teachers do call on them more often (Sadker, Sadker\&Khein 1991). Probably because boys are more verbally aggressive (Alternate Jovanomic\& Perry 1998).

\section{Teaching Experience}

Experience is a phenomenon defined as accumulation of knowledge or skill that results from direct participation of events or activities that are capable to organize and executes courses of action. The knowledge and awareness of the abilities the teachers have acquired over the years create in them a strong confidence that makes them believe that they can succeed in school work. The knowledge and the awareness of what teachers possess for years can make them to perform or discharge their duties effectively and this affects student's academic performance to be high. Experience could therefore be said to play a major role in student's performance.

Students taught by teachers of low experience might be seen to poses low emotion/intelligence because ideas or perceptions might reduce determination and quest to go about the issue at stake. On the contrary, students taught by highly experienced teachers with a stronger or high sense of efficacy are motivated by obstacles to channel their attention and effort to find out the cause of a problem and what to do to resolve it. According to Adeyemo (2001), highly performed students relate failure to insufficient effort while the low performed ones attribute it to inexperience of teacher in teaching. Academic performance is one of the social behaviours that are influenced by several cognitive factors among which teaching experience stands out distinct. Bandura (1977) cited in Uba (1987) seems to agree with this notion. He claimed that learning is medicated by cognitive factors such as mastery of the subject. Experience teachers when developing lessons they need to find topics lively and of interest to students. Parry (1998) et al, noted that for best academic achievement school authorities should introduce information in new and exciting ways and such schools located in rural areas where social amenities are lacking will have a negative effect on the students

Helen and Vigdor (2007) have found that teacher's experience has a significant positive effect on student achievement, with more than half of the gains accruing during the teacher's first few years, but substantial gains accruing over subsequent years. Novice teachers are often thrown into chaotic situations, it may take them a year to get their bearings, especially when they are asked to teach a subject outside their field or teach more than one subject. This will in turn affect the academic performance of students especially subjects like Mathematics, because the years of teachers experience is not enough while experience teachers with substantial years of teaching can overcome any situation at all. An experience teacher offer insight, knowledge and wisdom whether directly or indirectly over time.The level of experience of a teacher's instruction has a great effect on student's performance. The point is that life experience and compete attention to a subject affect all sorts of ways, large or small. Repetition beings not only fluency, but insight. That is when you teach a subject over and over especially a subject you know and love you see more in it and find different ways of presenting it. Your repertoire grows; you have more materials, ideas, and lessons. Experienced teachers know how to reach out to the students and cannot be affected by the days or year's ups and downs 
distractions and interruptions. Experienced teachers help to keep schools and purpose intact when such go through upheavals every few years.

Mugun (1996) of the opinion that in order to ensure that school has the proper image of what a school should be, well trained and experienced teachers should be provided by the management of educational institution. The major reason for this is that the level of training of a teacher has influence in his/her understanding of the curriculum, his or her ability to bring the students to an interactive situation, his/her understanding of the students. The teacher's methodology and level of awareness will provide solutions to learning problems with regards to years of experience.

An experienced teacher will be able to let parents know that certain home situations do affect the child, which may be expressed in the child's show of lack of interest in Mathematics when there is no cordial relationship between the home and the school.

Edhebe (2004), pointed out that in any innovation the attitude and the degree of receptivity of classroom teachers is important, if the innovation would succeed. Student's high academic performance due to innovations in teaching methods depends on the teaching experience of the teachers. It is therefore, very important that the teachers should have a positive disposition towards any new idea that is being introduced into the educational system. Emeke (1999) supported the above fact that teacher's years of experience and attitude towards any new methodology of teaching indicate a statistical significance in the implementation of that new methodology.

Okpala, Onocha and Oyedeji (1993) opined that teachers' integrity is fundamental in the implementation and practice of Mathematics skill. The researcher is of the view that the integrity of the teacher as well as the experience are good combination in the practice and demonstration of Mathematical innovations, due to it's complexity of the subject. An experienced teacher is expected to teach each unit of the curriculum effectively and efficiently, using appropriate evaluation instrument and report on each student objectively and utilize the feedback to improve instruction. Enueme (2002) pointed from her study with UNICEF recommendation for child friendliness with school is influenced by their teaching experience that those with high teaching experience accepted UNICEF recommendation for child friendliness to school. The acceptance highest level of teacher with 26 years of experience and above.

Finally, Arasteh (1966) says unqualified teacher will not be highly efficient in their tasks to improve the students' performance in their respective subjects in order to produce the right calibre of students, we have to recognize that ability to reason, develop with background, experience and training. We can at this point say that.

Better qualified teachers will produce better students' academic performance

1) The longer the teacher's years of experience and qualification, the better the performance of his students.

2) Teachers marital status that is married teachers have greater impact on students' academic performance in mathematics because married teachers appeared more devoted and dedicated to duties.

\section{Teachers Marital Status}

Marital status refers to the state of someone being single or married. Good achievement in schooling could be the partial contributions of teachers' marital status (Akerman, 2010). 
According to Bandura (1989) there is a friendly relationship among personal factors such as the teaching profession and behavoural characteristics such as Self-efficacy. Isahi and Nelson (2013) found that the influence of marital status and teachers' effectiveness was significantly different between the married and unmarried teachers. On the other hand, Yilmaz and Cavas (2008) Study reported a change in teachers Self-efficacy in classroom management with time without considering whether the teachers had changed marital status over that period.

Bagaka (2011) found that there is a significant influence between married and unmarried teachers. Ngunah (2012) study in Machakos, Kenya established that marital status of teachers influence work force with 75 percent of married teachers experiencing more work force than single, divorce and separated teachers did.

Roussanov and Savor (2013) study found difference in the teaching and management styles of married and unmarried teachers in favour of single teachers. Though the study was a pure qualitative study conducted with mixed methods of study conducted on Kenyan teachers not United States.

Chaturvedi and Parushothaman (2009) study revealed that marital status was a significant determinant of students' academic achievement among secondary school students, the findings of the study showed that single teachers hold better teaching strategies and time management of students.

Sarumi (1990), in found a significant difference between married and single teachers' method of teaching and teacher-student relationship. Similarly, Kayode (2013) in his study found a significant difference between married and single teachers on student's academic achievement. This also is agreement with the finding of Sarumi (1990) in a related study.

Research confirms that teachers marital status predict favourable development to children and adolescents of diverse family academic achievement. Gutman, Brown and Akerman (2010) conducted a study in United Kingdom (UK) to examine how married and single teachers' characteristics and contractual sources predict students' academic achievement. They found that marital status does not have a significant measurable direct effect on students. Therefore, marital status is not related to student academic achievement. Roman (2011) investigated single and married teachers in South Africa. He found that there was no significant difference between single and married teachers. Likewise, Avison, Ali and Walters (2007) and Greitemeyer (2009) found no significant difference in teaching between single and married teachers in South Africa. However, Aronson and Huston (2004) pointed out that compared with married teachers, single teachers are more likely to engage in inconsistent in teaching. They stated that single teachers are less likely to interact with their students in a more stimulating and maturating manner.

\section{Age of Teachers}

Academic performance has been seen as one of the most important goals of educational process. It has been of concern to various stakeholders in the society. The desire for a high level of performance puts a lot of pressure on students, teacher, schools and in general, the education system itself. Academic performance is the result obtained by students or grades awarded to them after a series of teaching and learning between teachers and learners.

It is through academic performance that adolescents learn about their talents, ability and their competencies which are important part of developing career aspirations. Usman (2000) sees 
academic performance as the measure of students' learning or acquisition of certain skills at the end of teaching and learning activities.

Age is referred to as a period of the time in life at which one attains full personal rights and capacities. Wikipedia Encyclopedia (2000) defines ape as the period of time at which some particular power or capacity is understood to become rested.

Abubakar and Oguguo (2001) posted that teachers irrespective of age can impact knowledge on the students effectively, in their findings they submitted that age of teachers does not influence the academic achievement of students. Ajila and Olutola (2000), confirmed that teachers' age, gender and socio-economic status have been found not to have impact on students' academic achievement. Huang, (2007) Opined that teachers age does not predict students academic achievement, Teachers age either old or young, male or female do not relate to students achievement. To him teaching ability of teachers is as a result of knowledge and teaching skills irrespective of age or gender. In his summary, a teacher can be aged and lacked knowledge and skills as well as young teacher. Feldman (2003) also found that age was not significantly related to students' academic performance. McEvoy (2013) found that teachers' age was largely unrelated to students' academic performance.

Sotonwa (2013) Opined that there is a relationship between teachers age and students academic achievement. In his study, he compared old and young teachers' impacts on the academic achievement of students and found that old teachers had high teaching impact on students' academic achievement, this may be due to their experience.

Habibollah, Abdullah, Aizan, Jamaluddin and Kumar (2009) carried out a study on creativity, age and gender as related to students' academic achievement, the analysis of the findings shared interaction effect between teachers' age and gender as related to students' academic achievement. Confirming this, a study showed that the correlation between age and school achievement diminishes as teachers becomes older. Schools provide equalizing experiences and thus the longer the teachers teaches in the schooling process, the more the impact of the age and students achievement is diminished (White, 2012).

However, Anbuthasan and Balakrishman (2013) investigated the teaching competency of teachers in relation to gender, age and locality in Kanchipuran District of Tamitiadu State, they found that there is a significant difference between age group of school teachers in their teaching competency. They concluded that there is significance difference between 25-35 years of age and above 35 years of age. In the analysis the above 35 years of age teachers had better teaching competency than 25-35 years of age teachers. Also, in a study conducted by Amutha-Ranjini and Mohanasunaram (2012) and Titus and Annaraja (2012) reported significant difference between young and old teachers in their teaching competency in secondary schools. They submitted that young teachers are better than old teachers in their teaching competencies. This may be due that the old teachers have more duty consciousness, responsibilities and commitment at higher level than young teachers.

\section{Specialization of Teachers}

A competent teacher is a master of his/her professions. Such a teacher, according to the Illinois State Board of Education (ISBE, 2002), understand what it takes to transfer knowledge. This enables the teachers to teach the content he needs in an advanced level of knowledge. A specialized teacher is the one who is trained in a given course of study. Area of specialization enables the teacher to adequately address detailed questions in the field of study thereby 
enabling the teachers to demonstrate a clear conceptual and systematic understanding of the course content.

According to Nwachukwu (1990), if a teacher lack the necessary qualification, the students will be at risk.Koledoye (2011) also holds similar view. According to him, qualification is a significant predictor of job performance among school teachers.In a study conducted by Goldhaber and Brewer (1997) it was found that mathematics students that were taught by teachers with advance degree in Mathematics achieved higher score as compared to those whose teachers had no degree in Mathematics. All these have implication for effective teaching and learning of mathematics in secondary schools. The quality of mathematics teacher in terms of area of specialization and professional qualification will largely determine the teacher's mastery of the content and ability to initiate and innovate to make him efficient in teaching.

Usman (2003) argued that shortage of specialized teachers is responsible for the poor academic achievement observable among the students while Ademulegun (2001) argued that students taught by more specialized and experienced teachers in terms of knowledge of the subject matter perform better than those taught by less specialized but experienced teachers. The educational analysis carried out in Nigeria by the National Economic Empowerment and development Strategy (NEEDS, 2005) indicated that more than forty-nine percent (49\%) of the teachers in Nigeria are unspecialized and unqualified in teaching various school subjects to the secondary school students. The teachers teaching Mathematics as a subject in the various secondary schools would probably be among the said forty-nine percent of unspecialized and unqualified teachers.

\section{Empirical Findings}

Okafor (2004) undertook a study on Human Resource Variables and Students' performance. The study used four research questions and four hypotheses were raised to guide the study. A population comprised all public senior secondary schools teachers and SSS 3 students in Egor Local Government Area of Edo State. A total of eleven (11) senior secondary schools were used and $80 \%$ of the teachers were used. With a total of 160 teachers.

The instrument for data collection was questionnaire used to elicit information from the teachers. The data collected were analysed using Pearson Product Moment correlation Coefficient to determine the relationship between dependent and independent variables. The findings revealed that some human resources variables such as gender difference and teaching experience are negatively related to student performance while staff qualification are positively related to students' performance.

Genda (2012) carried out a study on preparing students for higher performance in external examination in Delta State. The study focused on the roles of the teachers as an important element in the curriculum process which involves curriculum planning and implementation. The teachers should be familiar with what objectives and content there in the curriculum so that he or she would focus on the attainment in the classroom practices that will enhance higher student academic performance. The study emphasised staff qualification and better working environment that encourage the teachers to put in their best to imparting their knowledge which in turn positively affect the student in their academic performances. Having good knowledge of the subject area greatly depends on the qualification of the teacher experience in that subject and helps to improve the understanding of the students, thus enhances higher academic performance. 
The study concluded that there were some other variables that has relationship with student academic performance in external examinations. The study recommended that staff condition of service be improved in area of salary and other entitlements like leave allowances, gratuity, promotion. This form of improvement is good. The physical environment such as well equipped staffroom and classroom, adequate laboratory and library facilities be also attended to so that staff and students be conducive which in turn will reflect on the students academic performance.

The study also recommended that in the area of staff qualification, qualified staff be employed in educational institutions to be knowledgeable in their subject areas and this thus improves the academic performance in external examinations.

\section{Research Questions}

The following research questions guided the study:

1) What is the extent of relationship between staff qualification and students' academic performance in Mathematics in Senior Secondary Schools in Delta South Senatorial District?

2) What is the extent of relationship between Gender differences and students' academic performance in Mathematics in Senior Secondary Schools in Delta South Senatorial District?

3) What is the extent of relationship between teaching experience and students' academic performance in Mathematics in Senior Secondary Schools in Delta South Senatorial District?

4) What is the extent of relationship between teachers' marital status and students' academic performance in mathematics in Delta South Senatorial District?

5) What is the extent of relationship between Age of teachers and students' academic performance in mathematics in Delta South Senatorial District?

6) What is the extent of relationship between specialization of teachers and students' academic performance in mathematics in senior secondary schools in Delta South Senatorial District?

7) What is the extent of relationship between staff qualification, gender difference, teaching experience, marital status, age of teachers, specialization of teachers and students' academic performance in Delta South Senatorial District?

\section{Hypotheses}

The following null hypotheses were tested:

Ho 1. There is no significant relationship between staff qualification and students' academic performance in Mathematics in Senior Secondary Schools in Delta South Senatorial District.

Ho 2. There is no significant relationship between gender differences and students' academic performance in Mathematics in Senior Secondary Schools in Delta South Senatorial District.

Ho 3. There is no significant relationship between teaching experience and students' academic performance in Mathematics in Senior Secondary Schools in Delta South Senatorial District.

Ho 4. There is no significant relationship between teachers' marital status and students' academic performance in Mathematics in Senior Secondary Schools in Delta South Senatorial District.

Ho 5. There is no significant relationship between Age of teachers and students' academic performance in Mathematics in Senior Secondary Schools in Delta South Senatorial District.

Ho 6. There is no significant relationship between specialization of teachers and students' academic performance in Mathematics in Senior Secondary Schools in Delta South Senatorial District. 
Ho 7. There is no significant relationship between staff qualification, gender difference, teaching experience, marital status, age of teachers, specialization of teachers and students' academic performance in Mathematics in Senior Secondary Schools in Delta South Senatorial District.

\section{Design of the Study}

\section{METHOD}

It is a correlational method of ex-post facto research design. It will help to determine the relationship between staff qualification, gender difference, teaching experience, marital status, Age of teachers, Specialization of the teacher and student academic performance.

\section{Population}

The population of the study consisted of senior public Secondary School teachers in Delta South Senatorial District. There are 107 public Schools in the Delta South Senatorial District with a total teachers strength of 2,721. (Source: Post Primary Schools Board, Asaba).

\section{Sample and Sampling Techniques}

There are 107 public Secondary Schools in Delta South Senatorial District composed of eight (8) Local Government Areas. Five of these schools were sampled from each Local Government Areas through simple random sampling of balloting making Twenty (40) Senior Secondary Schools as a sample. Therefore, a total number of Twenty (40) Senior Secondary Schools teachers were selected through proportionate stratified random sampling technique. Eighty percent $(80 \%)$ of the teachers in each sampled school thus making a total of 870 teachers that were used. Teachers were selected through proportionate stratified random sampling techniques. The SS2 promotion examination scores of 2014 were used as secondary data.

\section{Instrument of the Study}

Two instruments were used for this study, the Basic and Secondary School Mathematics promotion examination for SS2 in Delta State and questionnaire for teachers. The data on students' academic performance were collected from mathematics promotion examination while the information on human resource variables was obtained from the teachers through questionnaire administration.

\section{Validity of the Instrument}

The instrument was validated by the researcher's supervisor and one other expert in measurement and evaluation and two Mathematics teachers and they found that the items in Basic and Secondary School Mathematics promotion examination for SS2 match the mathematics curriculum. The instrument have content and face validity.

\section{Reliability of the Instrument}

In establishing the reliability of the general research instrument, of the study, test-retest is used for estimating stability. Reliability refers to the consistency of the evaluation result. To determine the reliability of the instrument, the Basic and Secondary School Mathematics promotion examination question paper was administered twice after two weeks interval to thirty (30) students who are not part of the sample. The scores were correlated using Pearson product moment correlation and a correlation coefficient of 0.72 was obtained as a measure of stability.

\section{Method of Data Collection}

The researcher personally visited all the Schools sampled to collect students' scores on Basic and Secondary School Mathematics promotion examination and information on staff 
qualification and staff experience in the eight Local Government Areas of Delta South Senatorial District of Delta State.

\section{Method of Data Analysis}

The data collected were analyzed using coefficient of determination and regression statistics to answer the research questions and test the hypotheses. The relationship between each human resource variable and students' academic performance were determined and the amount of contribution of each human resource variable to performance. The hypotheses were tested at 0.05 level of significance.

\section{Research question 1}

\section{RESULTS}

What is the extent of the relationship between Staff qualification and Students' Academic Performance in Mathematics in Senior Secondary Schools in Delta State?

Table 1: Correlation Analysis of Staff Qualification and Students' Academic Performance in Mathematics in Senior Secondary Schools in Delta State.

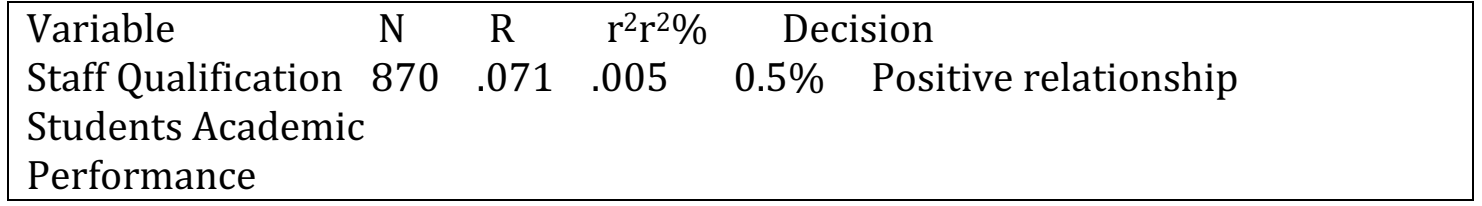

Table 1 , shows that $R=.071$ is the extent of the relationship between staff qualification and students academic performance in Mathematics. The coefficient of determination is .005 and the amount of contribution of staff qualification to students' academic performance is $0.5 \%$. The result shows a low positive relationship between staff qualification and students' academic performance. Staff qualification contributed to students' academic performance in Mathematics.

\section{Research Question 2}

What is the extent of relationship between sex of teachers and students' academic performance in mathematics in Delta South?

Table 2: Correlation Analysis of Sex and Students' academic performance in mathematics.

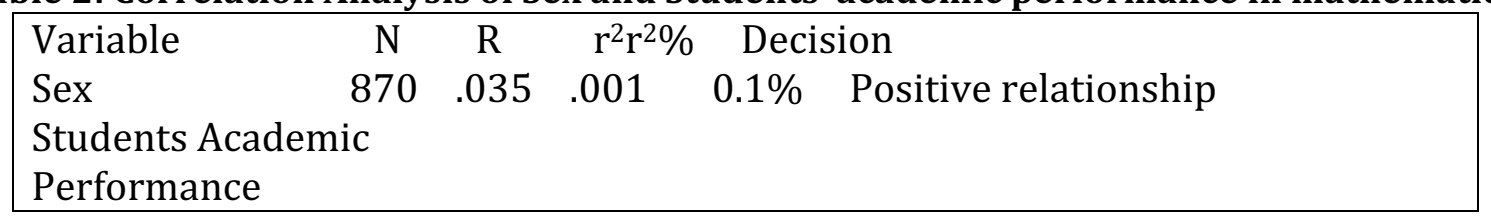

Table 2, shows that $\mathrm{R}=.035$ is the extent of the relationship between sex and students academic performance in Mathematics. The coefficient of determination is .001 and the amount of contribution of sex to students' academic performance is $0.1 \%$. The result revealed a low positive relationship between sex and students' academic performance.

\section{Research Question 3}

What is the extent of relationship between Teaching Experience and Students' academic performance in mathematics? 
Table 3: Correlation Analysis of Teaching Experience and Students' Academic Performance in Mathematics.

\begin{tabular}{|llllll|}
\hline Variable & $\mathrm{N}$ & $\mathrm{R}$ & $\mathrm{r}^{2} \mathrm{r}^{2} \%$ & \multicolumn{2}{c}{ Decision } \\
Experience & 870 & .075 & .006 & $0.6 \%$ & Positive relationship \\
$\begin{array}{l}\text { Students Academic } \\
\text { Performance }\end{array}$ & & & & \\
\hline
\end{tabular}

Table 3, shows that $\mathrm{R}=.075$ is the extent of the relationship between teaching experience and students academic performance in Mathematics. The coefficient of determination is .006 and the amount of contribution of teaching experience to students' academic performance is $0.6 \%$. The result shows a low positive relationship between the teaching experience and students' academic performance in mathematics. It also shows that teaching experience contributed to students' academic performance in Mathematics.

Research Question 4What is the extent of relationship between teachers Marital Status and students' academic performance in mathematics in Delta Senatorial District?

Table 4: Correlation Analysis of Teachers Marital Status and Students' Academic Performance in Mathematics.

\begin{tabular}{|lcllll}
\hline Variable & $\mathrm{N}$ & $\mathrm{R}$ & $\mathrm{r}^{2} \mathrm{r}^{2} \%$ & \multicolumn{2}{c}{ Decision } \\
Marital Status & 870 & .039 & .002 & $0.2 \%$ & Positive relationship \\
Students Academic & & & & \\
Performance & & & & & \\
\hline
\end{tabular}

Table 4, shows that $\mathrm{R}=.039$ is the extent of the relationship between teachers marital status and students academic performance in Mathematics. The coefficient of determination is .002 and the amount of contribution of marital status to students' academic performance is $0.2 \%$. The result revealed a low positive relationship between the two variables.

\section{Research Question 5}

What is the extent of relationship between age of teachers and students' academic performance in Mathematics in Delta Senatorial District?

Table 5: Correlation Analysis of Age of Teachers and Students' academic performance in mathematics.

\begin{tabular}{|lccccc|}
\hline Variable & $\mathrm{N}$ & $\mathrm{R}$ & $\mathrm{r}^{2} \mathrm{r}^{2} \%$ & \multicolumn{2}{c|}{ Decision } \\
Age & 870 & .057 & .003 & $0.3 \%$ & Positive relationship \\
Students Academic & & & & \\
Performance & & & & \\
\hline
\end{tabular}

Table 5, shows that $\mathrm{R}=.057$ is the extent of the relationship between age and students academic performance in Mathematics. The coefficient of determination is .003 and the amount of contribution of age of teachers to students' academic performance is $0.3 \%$. The result shows a low positive relationship between age and students' academic performance.

\section{Research Question 6}

What is the extent of the relationship between Specialization of Teachers and students' academic performance in Mathematics in senior secondary schools in Delta South? 
Table 6: Correlation Analysis of Specialization of teachers and students' academic performance in Mathematics.

\begin{tabular}{|lccccc|}
\hline Variable & $\mathrm{N}$ & $\mathrm{R}$ & $\mathrm{r}^{2} \mathrm{r}^{2} \%$ & \multicolumn{2}{c}{ Decision } \\
Specialization & 870 & .067 & .004 & $0.4 \%$ & Positive relationship \\
Students Academic & & & & \\
Performance & & & & & \\
\hline
\end{tabular}

Table 6 , shows that $\mathrm{R}=.067$ is the extent of the relationship between specialization of teachers and students academic performance in Mathematics. The coefficient of determination is .004 and the amount of contribution of specialization to students' academic performance is $0.4 \%$. The result shows a low positive relationship between the two variables. This implies that specialization of teachers contributed to students' academic performance in Mathematics.

\section{Research Question 7}

What is the extent of relationship between staff Qualification, Sex of Teachers, Marital Status, Age of Teachers, Teaching Experience, Specialization and Students' Academic Performance in Mathematics?

Table 7: Correlation Analysis of Staff Qualification, Specialization, Sex of Teachers, Marital Status of Teachers, Age of Teachers, Teaching Experience, Specialization and Students' academic Performance in Mathematics.

\begin{tabular}{|lrrrrrr}
\hline $\begin{array}{l}\text { Variable } \\
\text { Staff Qualification }\end{array}$ & $\mathrm{N}$ & $\mathrm{R}$ & $\mathrm{r}^{2} \mathrm{r}^{2} \%$ & Decision \\
Sex & & & & & \\
Experience & 870 & .176 & .031 & $3.1 \%$ & Positive relationship \\
Marital Status & & & & & \\
Age & & & & & \\
Specialization & & & & \\
$\begin{array}{l}\text { Students Academic } \\
\text { Performance }\end{array}$ & & & & \\
\hline
\end{tabular}

Table 7, shows that $\mathrm{R}=.176$ is the extent of the relationship between staff qualification, sex, teaching experience, teachers marital status, age of teachers, specialization of teachers and students academic performance in Mathematics. The coefficient of determination is .031 and the amount of contribution of staff qualification, sex, teaching experience, marital status, age and specialization of teachers to students' academic performance in mathematics is $3.1 \%$. This result shows a low positive relationship. the two variables. The result indicated that Staff qualification, sex, teaching experience, marital status, age of teachers and specialization of teachers contributed to students' academic performance in Mathematics.

\section{Hypothesis 1}

There is no significant relationship between staff qualification and students' academic performance in mathematics. 
Table 8: Regression Analysis of Staff Qualification and Students' academic Performance in Mathematics.

Model Summary

Model R R Square Adjusted R Square Std. Error of the Estimate

$1 \quad .071 \quad .005 \quad .004$ 10.06074

ANOVA

\begin{tabular}{llccccc}
\multicolumn{1}{l}{ Model } & Sum of Squares & df & Mean Square & F & Sig. \\
1 & Regression & 439.944 & 1 & 439.944 & 4.346 & .037 \\
& Residual & 87857.716 & 868 & 101.219 & & \\
Total & 88297.660 & 869 & & &
\end{tabular}

Coefficients

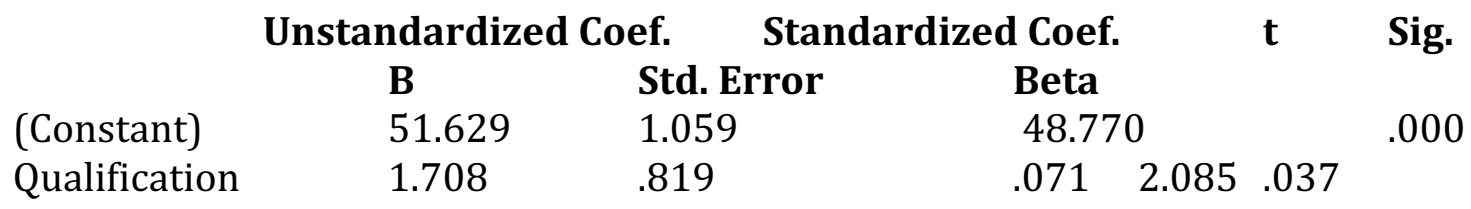

Table 8 shows an $F$ value 4.346 and a p value of .037. Testing at an alpha level of . 05 the $p$ value is less than the alpha level, so the null hypothesis which states that there is no significant relationship between staff qualification and students' academic performance in mathematics is rejected. Hence, the result indicates that there is significant relationship between staff qualification and students' academic performance in mathematics.

\section{Hypothesis 2}

There is no significant relationship between teachers' sex and students' academic performance in mathematics.

Table 9: Regression Analysis of Teachers Sex and Students' Academic Performance in mathematics.

\section{Model Summary}

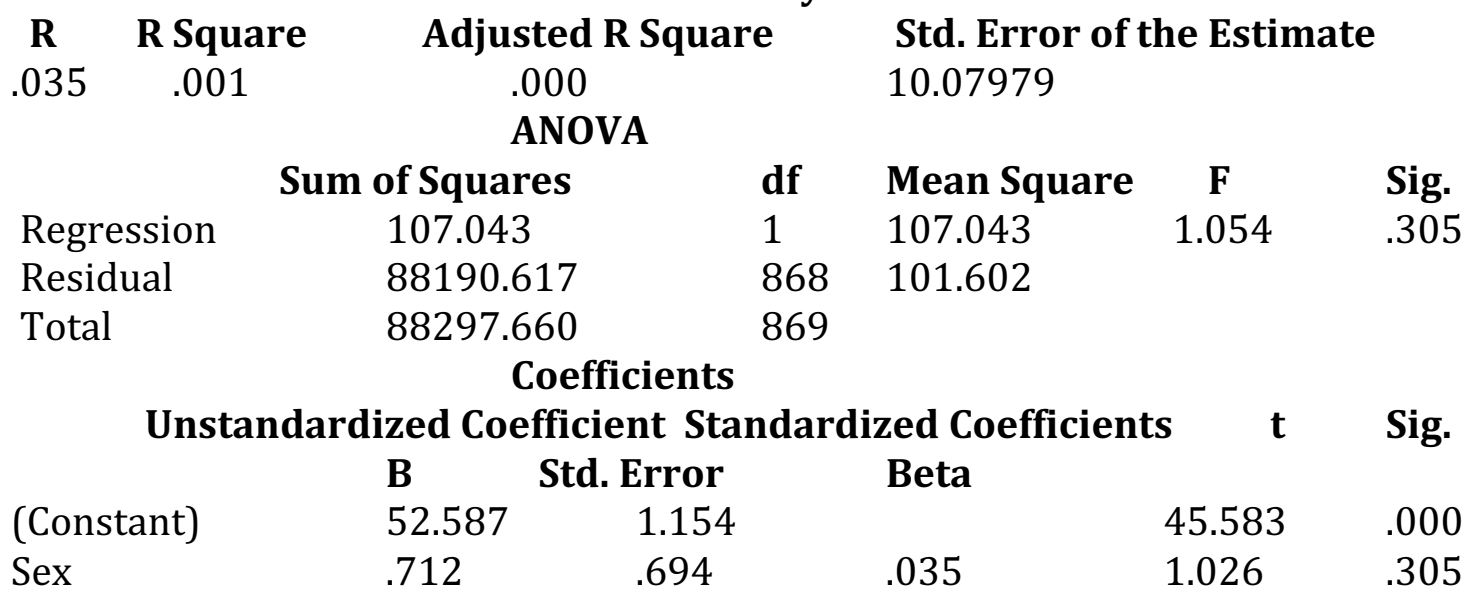

Table 9 revealed the regression output which showed a linear relationship between teachers' sex and students' academic performance in mathematics. The computed $\mathrm{F}(1,868)=1.054 \mathrm{P}>$ 0.05. Hence, the null hypothesis which state that there is no significant relationship between Teachers sex and students' academic performance in mathematics is retained.

This result indicate that there is no significant relationship between Teachers sex and students' academic performance in mathematics. 


\section{Hypothesis 3}

There is no significant relationship between teaching experience and students' academic performance in mathematics.

Table 10: Regression Analysis of Teaching Experience and Students' Academic Performance in mathematics.

\section{Model Summary}

\begin{tabular}{|c|c|c|c|c|c|c|}
\hline \multirow{3}{*}{$\begin{array}{l}\mathbf{R} \\
.075\end{array}$} & are & Adjusted & quare & \multicolumn{3}{|c|}{ Std. Error of the Estimate } \\
\hline & \multicolumn{3}{|c|}{ ANOVA } & & & \\
\hline & Sum & f Squares & df & Mean SquareF & Sig. & \\
\hline gression & & .099 & 1 & 500.099 & 4.944 & .026 \\
\hline sidual & & 97.562 & 868 & 101.149 & & \\
\hline Total & & 97.660 & 869 & & & \\
\hline
\end{tabular}

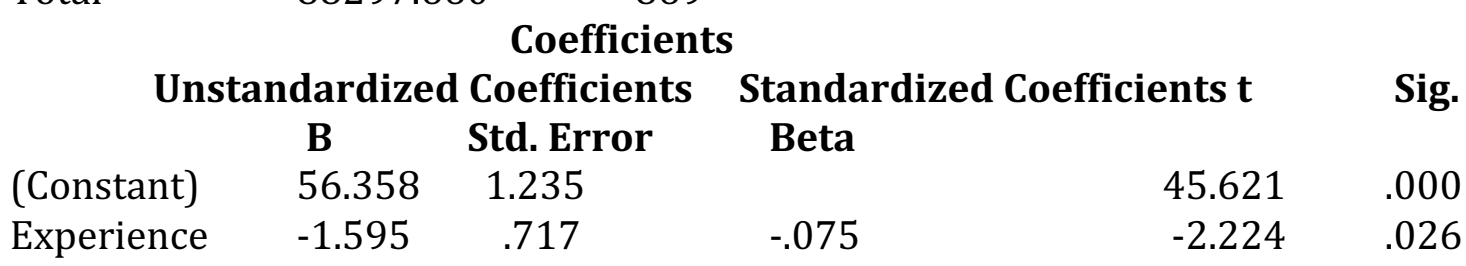

The result in table 10 shows the regression output of a linear relationship between teaching experience and students' academic performance in mathematics. The computed $\mathrm{F}(1,868)=$ $4.944 \mathrm{P}<0.05$. Hence, the null hypothesis is rejected. This implies that there is significant relationship between teaching experience and students' academic performance in mathematics.

The $\mathrm{R}^{2}$ adjusted value of .005 showed that $5 \%$ of variance in students' academic performance in mathematics was accounted for by teaching experience. The unstandardized regression coefficient (B) for predicting students' academic performance from teaching experience was -1.595 , while the standardized coefficient $(\beta)$ was $-.075, \mathrm{t}=-2.224$. Therefore, teaching experience was significant at $\mathrm{P}-$ value of 0.05 .

\section{Hypothesis 4}

There is no significant relationship between marital status and students' academic performance in mathematics.

Table 11: Regression Analysis of Marital Status of Teachers and Students' Academic Performance in mathematics.

\section{Model Summary}

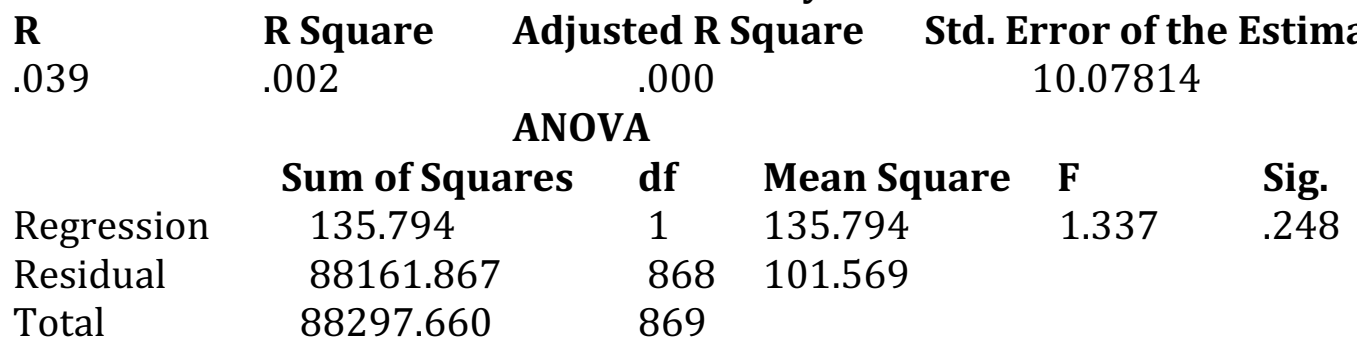

\begin{tabular}{|c|c|c|c|c|c|}
\hline \multicolumn{3}{|r|}{ Coefficients } & \multicolumn{2}{|c|}{ Standardized Coefficients $t$} & \multirow[t]{2}{*}{ Sig. } \\
\hline & B & Std. Error & Beta & & \\
\hline & 52.596 & 1.029 & & 51.135 & .000 \\
\hline al Status & .817 & .706 & .039 & 1156 & .248 \\
\hline
\end{tabular}


Table 11 shows the regression output of a linear relationship between marital status and students' academic performance in Mathematics. The computed $\mathrm{F}(1,868)=1.337 \mathrm{P}<0.05$. Hence, the null hypothesis was accepted. This showed that there was no significant relationship between marital status and students' academic performance in mathematics.

The $\mathrm{R}^{2}$ adjusted value of .000 showed that $0 \%$ of variance in students' academic performance in mathematics was accounted for by marital status. The unstandardized regression coefficient (B) for predicting students' academic performance from marital status was .817 , while the standardized coefficient $(\beta)$ was $.039, \mathrm{t}=1.56$. Hence, marital status was not significant at $\mathrm{P}-$ value of 0.05 .

\section{Hypothesis 5}

There is no significant relationship between age and students' academic performance in mathematics.

Table 12: Regression Analysis of Age of Teachers and Students' Academic Performance in mathematics.

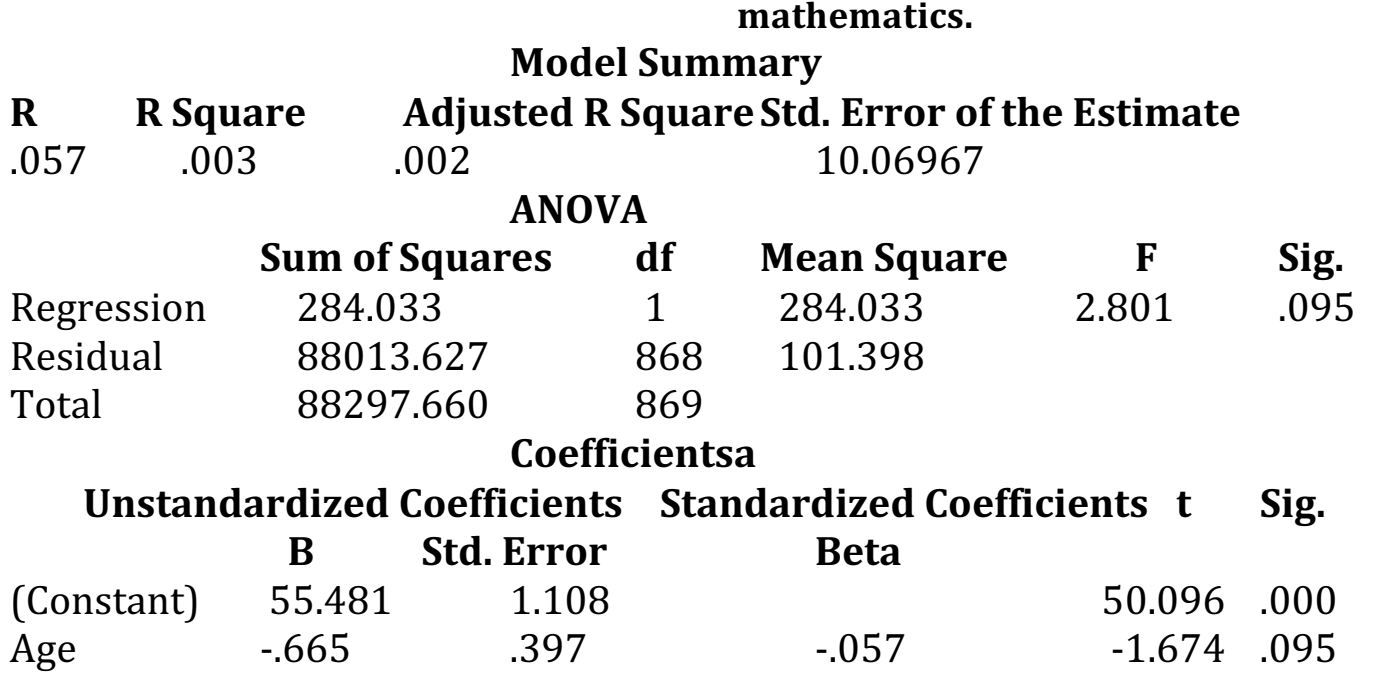

Table 12 shows the regression output which indicated a linear relationship between age and students' academic performance in mathematics. The computed $\mathrm{F}(1,868)=2.801, \mathrm{P}<0.05$. However, the null hypothesis was accepted. This revealed that there was no significant relationship between teachers' age and students' academic performance in mathematics.

The $\mathrm{R}^{2}$ adjusted value of .002 showed that $2 \%$ of variance in students' academic performance in mathematics was accounted for by teachers' age. The unstandardized regression coefficient (B) for predicting students' academic performance from teachers age was -.665, while the standardized coefficient $(\beta)$ was $-.057, t=-1.674$. Therefore, teachers' age was not significant at $\mathrm{P}$ - value of 0.05 . 


\section{Hypothesis 6}

There is no significant relationship between specialization of teachers and students' academic performance in mathematics

Table 13: Regression Analysis on Specialization of teachers and Students' Academic Performance in mathematics.

Model Summary

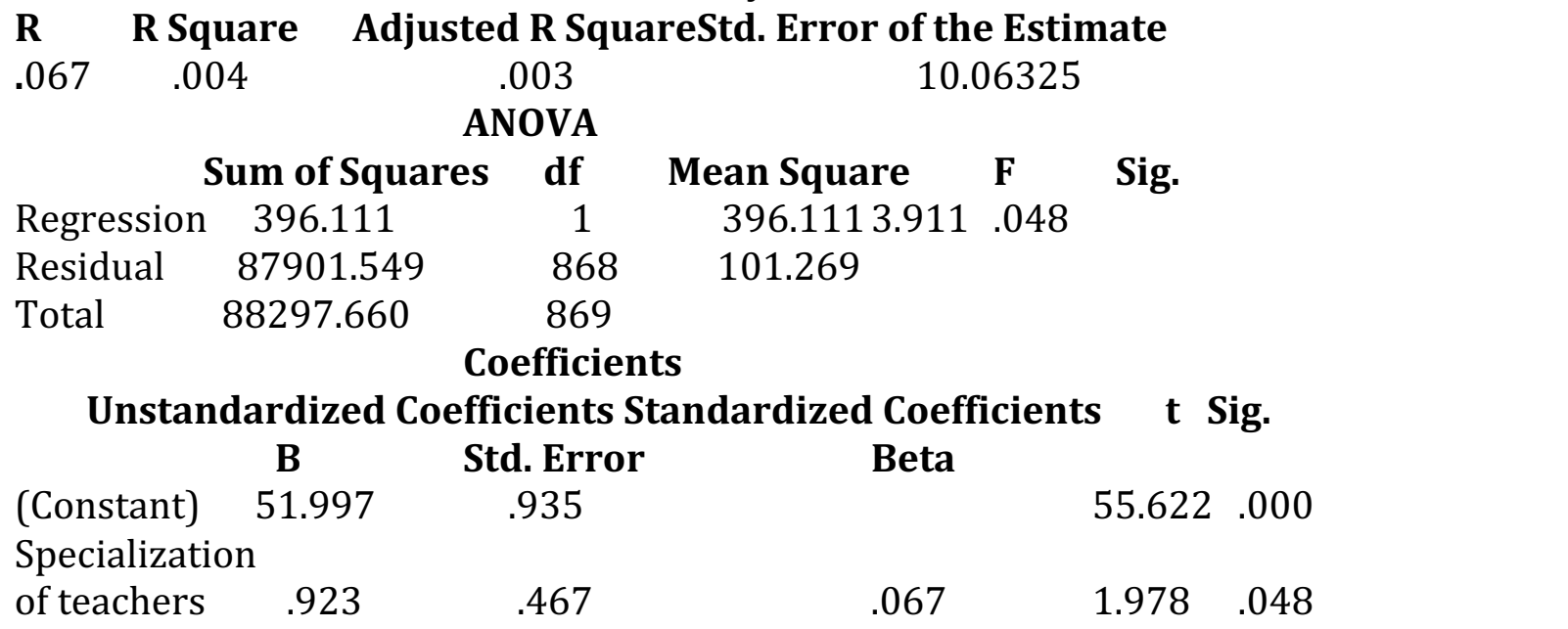

Table 13 indicated the regression output shows a linear relationship between specialization of teachers and students' academic performance in mathematics. The computed $\mathrm{F}(1,868)=$ 3.911, $\mathrm{p}<0.05$. Therefore, the null hypothesis was rejected. This implies that there was significant relationship between specialization of teachers and students' academic performance in mathematics.

The R2 adjusted value of .003 showed that $3 \%$ of variance in students' academic performance in mathematics was accounted for by specialization. The unstandardized regression coefficient (B) for predicting students' academic performance from specialization of teachers was .923, the standardized coefficient $(\beta)$ was $.067, t=1.978$. Therefore, specialization was significant at $\mathrm{P}$ - value of 0.05 . 


\section{Hypothesis 7}

There is no significant relationship between staff qualification, teachers' sex, teaching experience, marital status, age teachers, specialization of teachers, and students' academic performance in mathematics.

Table 14: Regression Analysis of Staff Qualification, Teachers' Teachers Sex, Teaching Experience, Marital Status, Age Teachers, Specialization and Students' Academic Performance in mathematics.

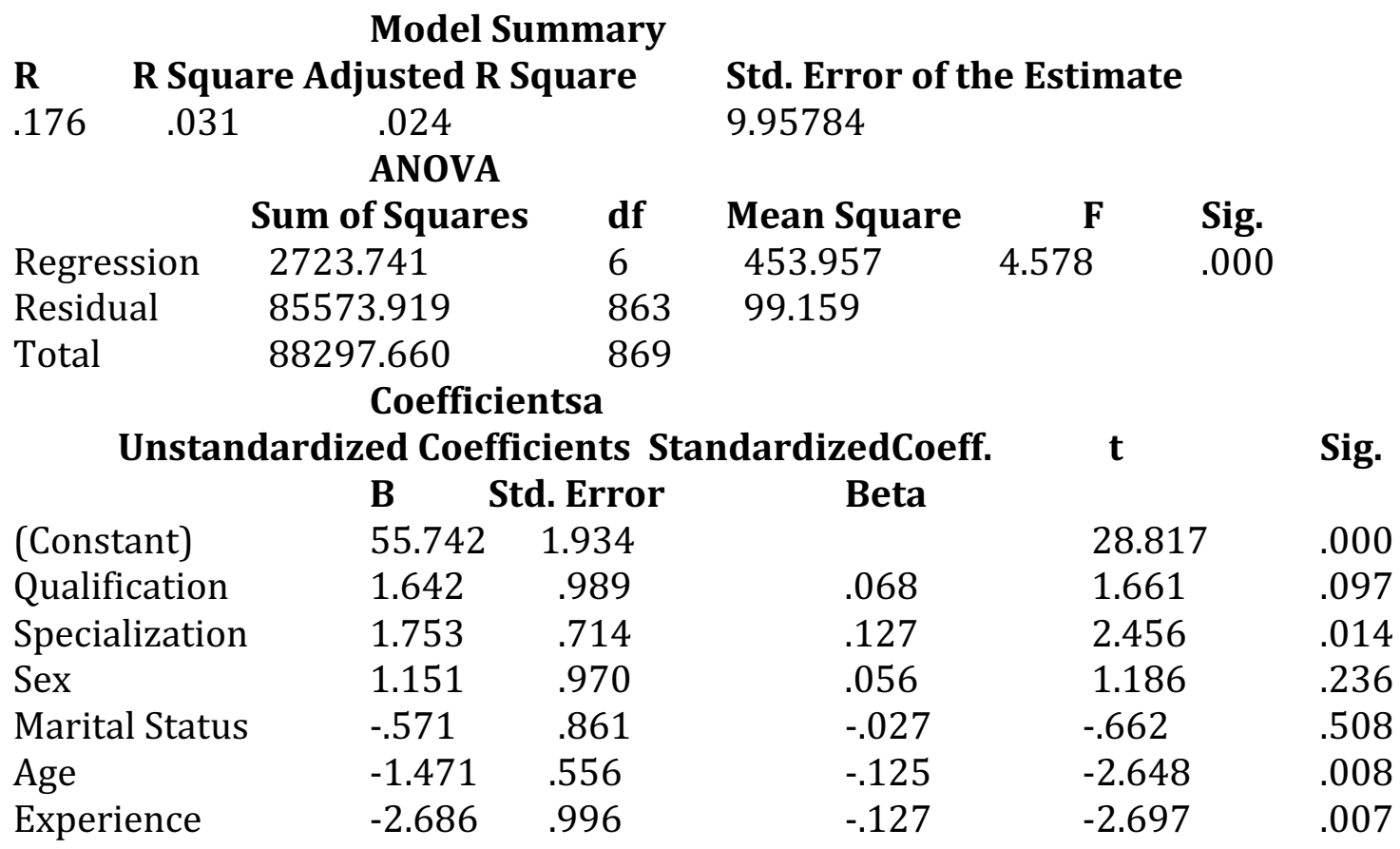

The result in table 14 shows the multiple regression output of a linear relationship between staff qualification, teachers' specialization, teachers' sex, marital status, teachers' age, teaching experience and students' academic performance in mathematics. The computed $\mathrm{F}(6,863)=$ $4.578, \mathrm{P}<0.05$. Hence, the null hypothesis is rejected. This showed that there is significant relationship between $\mathrm{t}$ qualification, specialization, teachers' sex, marital status, age, teaching experience and students' academic performance in mathematics.

The $\mathrm{R}^{2}$ adjusted value of .024 shows that $2.4 \%$ of the variance in students' academic performance in mathematics was accounted for by staff qualification, teachers' specialization, teachers' sex, marital status, teachers' age, teaching experience. The unstandardized regression coefficient (B) for predicting students' academic performance from staff qualification was 1.642 , specialization 1.753 , sex $=1.151$, marital status $=-.571$, teachers age $=-1.471$ and teaching experience $=-2.686$, the standardized coefficient $(\beta)$ for staff qualification was $.068, \mathrm{t}=1.661$; specialization $.127, \mathrm{t}=2.456$, teachers sex $=.056, \mathrm{t}=1.186$; marital status $=-.027, \mathrm{t}=-.662$; teachers age $=-.125, \mathrm{t}=-2.648$ and teaching experience $=-.127$, $\mathrm{t}=-2.697$. Hence, specialization, age and teaching experience teachers are significant while staff qualification, teachers marital status and sex are not significant.

\section{DISCUSSION}

The present study was carried out on human resource variables as correlates of Students' performance in Mathematics in Secondary Schools in Delta South Senatorial District.

The result of the first research question showed that there is positive relationship between Staff Qualification and Students' performance in Mathematics in Senior Secondary Schools in 
Delta South Senatorial District. The result confirmed the work of Odunsi (2000) noted that no matter how grandiose a School system and its programme are, the overall academic performance will be fruitless unless they are handled by competent and adequately qualified teachers.

This, finding also in line with the recommendation by Harmond (2000) that qualified teachers are better rated and more successful with students than teachers without adequate qualification.

The result of the first hypothesis showed that, on the basis of the data that emerged from the regressional analysis. Thus the null hypothesis is rejected meaning there is significant relationship between Staff Qualification and Students' performance in Mathematics in Secondary Schools.

The result of the second research question showed that there is positive relationship between Gender differences and Students' academic performance in Mathematics in Secondary Schools in Delta South Senatorial District. This result is in consonant with that of Balogun (1984) Osibodu (1985) and Williams (1987) affirmed that female teachers were not dedicated to duties and were not given educational opportunities as the males and females were discouraged from taking advanced courses in Mathematics.

The result of the second hypothesis revealed that there was positive relationship between teacher's sex and Students' academic performance in mathematics in Secondary Schools. This disagreed with Okoye (1983) \& Ogunleye (2000) noted that low academic performance due to employment of female in the teaching profession. Hence, the null hypotheses was accepted. This indicated that there was no significant relationship between teachers' sex and students' academic performance in Mathematics.

The result of the third research question indicated that there is a positive relationship between Teaching Experience and Students' academic performance in Mathematics in Secondary Schools in Delta South Senatorial District. This finding supports Adeyemo (2001), Ladd and Vigdor (2007) noted that teachers experience has a positive on student achievement. Kpeke (2001) reported that effective and prolonged learning in education harnesses on the teacher superior captures experience and skills and value which are imparted to effective performing of the numerous task of teaching.

The result of the third hypothesis revealed that there was significant relationship between Teaching Experience and Students' academic performance in mathematics in Secondary Schools. This result disagreed with Mugun (1996) of the opinion that well trained and an experienced teachers have influence in their understanding of the curriculum and thus enhances his or her ability to bring the students to an interactive situation. Hence, the null hypotheses was rejected. This implied that there was significant relationship between teaching experience and students" academic performance in Mathematics.

The result of the fourth research question showed that there is positive relationship between teachers' marital status and students' academic performance. This result agrees with Bagaka (2011) who noted that there is significant influence between married and unmarried teacher on students academic performance.

The result of the fourth hypotheses indicated that there was significant relationship between teachers' marital status and students' academic performance. This disagrees with Roman 
(2011) in his study in South African that there was no significant relationship between marital status of teachers and students' academic performance.

The result of the fifth research question revealed that there is positive relationship between Age of teachers and students' academic performance. This result is in agreement with Anbuthesan\&Balakrisha (2013) who opined that there is no relationship between teacher age and students academic achievement.

The result of the fifth hypotheses revealed that there was no significant relationship between teachers' age and students' academic performance in Mathematics, the null hypothesis was accepted. This disagrees with Anbuthesa and Krisha (2013)

The sixth research question revealed that there is low positive relationship between specialization of teachers and students' academic performance in Mathematics. This result agrees with Adodo (2007) who noted that success of students' academic achievement largely depends on specialization of teachers in that subject. Ibrahim (2000) believed that specialization of teachers and exposure can go a long way to bring about students' high academic achievement.

The sixth hypotheses revealed that there is positive relationship between specialization of teachers and students' academic performance in mathematics. The null hypothesis was rejected showing that there is positive relationship between specialization of teachers and students' academic performance. This result is in consonance with Usman (2003) arguing that shortage of specialized teachers is responsible for the poor academic achievement of students.

The result of the seventh research question showed that there is a positive relationship between staff qualification, sex of teachers, specialization of teachers, marital status, Age of teacher and students' academic performance in Mathematics. This result is in agreement with Okorodudu (1999) who reported that staff qualification is of fundamental relevance for effective and efficient in the secondary system. There is positive relationship between teaching experience and students' academic performance in Mathematics, this result agrees with Adeyemo (2001) who noted that teachers experience has positive impact on students' academic performance.

The result of the seventh hypothesis showed that there was a relationship between staff qualification, teachers' specialization of teachers, teacher sex, marital status, teacher ages, teaching experience and students' academic performance in Mathematics. Hence, the null hypothesis was rejected. This result is also in agreement with the findings of Adeyemo (2001) which indicated that low performance of students is attributed to inexperience of teachers in teaching.

\section{CONCLUSION}

Based on the findings of this study, the following conclusion was reached.

Staff qualification, specialization of teachers and teaching experience are related to students academic performance in mathematics. Teachers sex, marital status and age of teachers were not related to students academic performance in mathematics in senior Secondary Schools.

\section{RECOMMENDATIONS}

1) Staff qualification, specialization of teachers and teaching experience are related to students academic performance in mathematics. Teachers sex, marital status and age of 
teachers were not related to students academic performance in mathematics in senior Secondary Schools. More qualified and professional hands should be encouraged to engage in teaching Mathematics in other to avert the perennial dismal performance of students.

2) Mathematics teachers' workload should be such that it allows adequate content coverage and thus minimizes teaching towards passing the examination alone.

3) Government should employ qualified Mathematics teachers, train and retain them to be abreast with new innovations in the educational sector.

4) Parents should monitor the time their children spend in watching television and playing computer games. Some of this time if well utilized will bring improvement in the academic performance of students.

5) Teachers with NCE should strive to improve their knowledge in Mathematics by acquiring additional qualification through in-service training or part time or Sandwich degree programme in the Universities around their place of working.

6) Graduate teachers without teaching qualification should endeavour to proceed on PGDE or PDEprogramme to enhance their teaching method in Mathematics.

7) To this end, educational planners, administrators and evaluators should supervise, monitor and coordinate the activities of the School heads, teachers and students in the School system as well as appreciate the fact that the Parent Teacher Association, guidance and counselors, philanthropists, students and society at large have crucial role to play in improving students academic performance and hence solicit performance of the students.

\section{References}

Abubakar, R. B \&Ogugguo, O. D (2011) Age and gender as predictors of academic achievement of college mathematics and science students, in instructional conference on teaching, learning change institution (IML)

Ajila, C. \&Olutola, A. (2010) Influence of Teachers age on students' academic performance, Ife Journal of Educational Studies, 7(1): 31 - 39.

Anbuthasan, A. \& Balakrishnan, V. (2013) teaching competency of teachers in Relation to age, gender and locality. International Journal of Teachers Educational Research. 2(1),20-26

Abubakar I. (1978) Fallen Standard of Education, Factors responsible, New Nigeria June 12, 6 - 10

Afe, J. O. (2000), Reflections on Becoming a Teacher and challenges of Teachers Education, Inaugural Lecture Series, University of Benin, Benin City.

Ademulegun, D. (2001) Monitoring learning achievement of Junior Secondary School Students in Lagos. A photo type of state assessment. Unpublished Ph.D Thesis. University of Ibadan.

Adepoju, O. A (2002) Evaluation of the school consideration programme of the Nigerian conservation foundation. Unpublished M .Ed Dissertation, University of Ibadan, Ibadan.

Adeyemo, D. A. (2001). Teachers job satisfaction, job involvement, career and organizational commitments as correlates of student academic performance. Nigerian journal of applied psychology. 6(2), 126-135.

Adodo, 0. A (2007) Effect of remediation instructional strategies and students learning outcomes in junior Secondary School Integrated Science. Unpublished Ph.D Thesis, University of Ado-Ekiti, Ekiti State.

Agharuwho, A. A \&Nkachi, M. U (2006). Teachers' effectiveness and student academic performance in student Homer Community Science. Educational Administration and Policy studies, Delta State University, Abraka Nigeria. 3(2) Retrieved online on $9^{\text {th }}$ October, 2010.

Ajowole, G. A (1990) Why there are not enough Science applicants for university admission. Journal of Science Teachers Association of Nigeria, 20 (2) 90-99.

Alao, I. (2014) Teacher effectiveness among female teachers in primary and secondary Southwestern Nigeria. Journal of Educational Leadership in Action. Retrieved on $4^{\text {th }}$ June 2015 from http: //www.

Lindenwood.edu/ela/issue02.a/ao.html. 
Anukam, I. L (2001) Investigating Factors Influencing Primary School Pupils Learning Achievement in Imo State, In Current Issues in Educational Management in Nigeria (Eds) by NwagwuN.A, EhimetatorE.T, Ogunu M. A, Nwadiani M Benin City: Association for Educational Administration and Planning (NAEAP).

Aronson, S. R, \& Huston, A. C (2004) The Mother-Infant relationship in single, cohabitating, and married families. A case for marriage Journal of family psychology, 18(1)5-18.

Avison, W. R. \& Ali J., and Walters, D. (2007) Family structure, stress, and psychological distress. A demonstration of the compact of differential exposure. Journal of Health and Social Behaviour, 43(3), 301-317.

Ajayi, O. A (1981). New Educational policy of Nigeria Daily Times, Dec 5, 17.

Ayodele, J. B (1997) The Influence of teachers' Qualification on students' academic performance in social studies in Ekiti-State. Ife Journal of Educational Studies, 4(1), 42-47.

Bagaka, J. (2011) The role of teachers' characteristics and practices on upper secondary school students' Mathematics self-efficacy in Nyanza province of Kenya: A multilevel analysis. Informational Journal of science and Mathematics Education, 9 (4)817-842.

Balogun, T. A. (1984), Interest of Science and Technology Education in Nigeria. A paper at the $10^{\text {th }}$ International symposium of interest in Science and Technology, Kiel IPN, and UNESCO.

Bandura, A. (1989) Social Cognitive theory. In R. Vasta (Edu), Analysis of Child Development. Greenwich, CT: JAI Press 6, 1-60.

Bloom, B. S (1969) Stability and Change in Human Characteristics London: John Wolly and Son Inc.

Bollington, R. (1993) British Columbia Teachers Federation: Teachers Workload http//www.betf.bc.ca/issues in Education. aspx?id=5776

Bracey. G. W (1996), Socio-Economic Status and Involvement Annual Review of Psychology, http//www.Find Articles. COM

Caine, R. (2000) Building the Bridge from Research to Classroom. Educational Leadership. 58, 3, 59 - 62. Wilson Web July 18, 2001.

Chaturvedi, M. \&Parusthiaman T. (2009) Copping behaviour of female teachers. Demographic determinants. Industrial Psychiatry Journal, 18, (1) 36-38.

CKalvin, C. (1999) Double Promotion elementary/Middle School form: Cross Ref. Aps. Laicio J. (200). A Teacher Chance for immortality. The Educational Digest 65, 6, 44, 8,

Coleman, J. (1966). Equality of Educational Opportunity, Washington D. C Department of Health Education and Welfare offices of Education.

Darling- Harmond, L. (2000) Teacher's Quality and Student Achievement: A Review of State Policy Evidence, Education policy Analysis archives 8 (1), 23 - 30.

Edhebe, J. I. (2004), An Evaluation of Implementation of the Continuous Assessment Program.DELSU, Abraka. Unpublished Thesis.

Elvers, D (1978) Evaluating Executive Effectiveness Management in Nigeria, 14, 9 October, 6-14.

Enueme, P. C. (2002). Influence of School Location and Teaching Experience on Primary School Teachers Acceptance of the UNICEF Recommendations for Child - Friendly School" in refocusing Education in Nigeria (ed). Unpublished Thesis.

Federal Government of Nigeria, (2004) Public Service Review Commission: Main Report Federal Ministry of information.

Ehiametalor, E.T. (1983). The application of continuous assessment model in Nigerian schools. Ilorin journal of education, 24-32.

Evertson, C. Hawley, W., \&Zlortrik, M. (1985). Making a difference in educational through teacher education. Journal of teacher education, 36, (3) 2-12.

Fagbamiye, E. O. (1987). The Nigerian teacher in the 1980's. University of Lagos series in education. The art and science of education (2) 101. Lagos: Nelson publishers limited.

FME (2006). Operation Research All Secondary Schools: Report on the State Of Secondary Schools In Nigeria, (Eds)

M. J Shavaiba, E. R Ejenavi and V. $O$ Ochuba Federal Inspectorate Service, Ministry of Education, Abuja. 
Federal Ministry of Education (1993). New Policy on Education Lagos Government Press. National Policy on Education - $4^{\text {the }}$; NERDC press. 2004

Fafunwa, A. B. (1970). Teacher Education in Nigeria, West Africa Journal of Education 14 (1) 20 - 26.

Goldhaber, D. D \& Brewer, D. J (1997) Evaluating the effect of teacher Degree level on Educational performance. In W. J Fowler (Ed), Development in school Finance. Washington, D. C, National Centre for Educational statistics.

Greitemeyen T. (2009). Stereotypes of singles. Are singles what we think? European Social Psychology, 39(3), 367383.

Gutman, L. M, Brown J. \& Akerman R. (2010) Nurturing Parenting capability: Why Do Parents Parent the Way they Do? Extension Report in Predictors of parenting at five years. London Institute of Education.

Habibollah, N., Abdullahi, R., Arizan, H. T., Sharir, J \&Kurma, U. (2009). Creativity, age and gender as predictors of academic achievement among undergraduate students. Journal of American Science. 5(5): 101-111.

Hallack, Z (1990) Planning the Location of Schools an Instrument of Education Policy. Paris: UNESCO

Hayneman, S. P. (1983). Improving the Quality of Education in Developing Countries. Journal of Education and Development. 5, (4), 40 - 50.

Heyns, B. (1974) Social Selection and Stratification within Schools. American Journal of Sociology 79, (1), 88 - 99.

Huang, C. (2007). Academic interactions among classroom peers: across country comparison using TIMSS. Applied economics. 39(12):1531-1544.

Ibe, B. 0, \&Maduabum, M. A (2006) Teacher's Qualification and experience as correlates of secondary School Students' achievement in Mathematics Teachers' 40 th STAN Annual Conference Proceedings: 138-142.

Ibrahim, A. (2000). Evaluating the pedagogical competency of junior secondary school integrated science teachers' $40^{\text {th }}$ STAN annual conference proceeding. 138-142.

Ibukun, M. O. (2009) Build the future: Invest in teachers now. A paper presented at the Ondo State Word Teachers Day Monday $5^{\text {th }}$ October.

Igwe, D. O. (1990) Science Teachers qualifications and Students performance in secondary schools in Kano State. Journal of Science Teachers Association of Nigeria, 26 (2), 47-51

Illinois, State Board Of Education (ISBE, 2002) Illinois Professional Teaching Standard (2nd Ed) Retrieved April 6, 2000 from http: // www. Westga. Edu

Isahi F. \& Nelson, D. (2013) Who make effective teachers married or single? An Indian perspective. Universal, 21, 185-190.

Khan, Q. U. \&Bertecher D. (1988), The problem of repetition and drop out in Basic Education in Madagascar. Summary result of a Study Undertaken in cooperation with UNICEF and Ministry of Secondary and Basic Education. Paris Unit for cooperation with UNICEF and WPP, January, No 180.

Koledoye, J. D (2011) Effect of teachers' Academic specialization on students' performance at the secondary level. Retrieved from http: //www. academic. Edu.

Kpeke, E. E. (2001). Teacher in Contemporary Nigeria in V.F. Peretomode (ed) Sociology of Education Lagos; Obarah and Ogbinaka Publishers.

Levin, H. M. (1970) A Cost-Effective Analysis of Teachers Selection Journal of Human Resource 5 (1), 56 - 66.

Luocke, D. F. (1975) Regression Analysis and Education Predication Function: Can They be trusted? Harvard Edition Review 45, 35 - 42.

Maslow, A. H. (1954). Motivation and Personality New York: Harper.

Mugun, N. E. (1996) Environmental Influence on Students Learning: Ekpana: ever jolly publishers.

Needs, C. B (2005) National Economic Empowerment and Development Strategies National Planning Commission, Central Bank of Nigeria, Abuja, 3, 34-38.

Ngunah M. N (2012) Influence of work-family conflicts on secondary school teachers' level of job satisfaction in Machakos District, Kenya. Unpublished Thesis Department of Educational Administration. University of Nairobi.

Nunnally, J. (1978) Psychometric Theory, New York: McGraw Hill

Nwachukwu, F. C. (1990) teachers Qualification and area of J. S. C. in Mathematics in Ehime-Mbaro L. G. A of Imo State. (Unpublished M. Ed Thesis) university of Nigeria, Nsukka. 
Nwagu, F. O. (1984) An Analysis of Instructional Supervisory Performance of Secondary Grammar School Principal in Bendel State: An Unpublished M. Ed Project University of Benin, Benin city.

Ezewu, E. E. \&Adejumo (1985). Theory and Practice of Education. Lagos: Basic books Publishers.

Obiolor, O. O. (1973), The Falling Standard of Education Daily times $7^{\text {th }}$ July.

Ofoegbu, G. $O$ (2004) Teachers' Influence in motivating Students to read and appreciate literature. Nigerian Journal of Counselling and Applied Psychology, 2(1), 202-210.

Okebukola, P. A, (1989) Some passage, Content and process variables relative to students' achievement in biology. Journal of Science Teacher Association of Nigeria, 24(1 and 2), 171-176.

Ogunleye, A. O. (2006). A survey of students' performance in science. Lagos State of save science education. Appeal fund'. Journal of Nigeria Lagos. 15-20.

Okorodudu, R. T. (1999) Selected Personality Traits and Motivational Indices as Correlates of Work Attitude of Teachers in Secondary Schools in Delta State. Unpublished Ph.D Thesis, University of Benin, Benin City, Nigeria

Okwudiaba, B. U. (2001) Middle School to High School accelerated promotion guidelines http/www.lngenta. Connect. Co/content/ bpsoc/15 July 2002

Oloyede, A. (1992) A Comparative Analysis of the school certificate performance in Mathematics of professionally trained and unprofessionally trained teachers in Lagos State. Journal of Science Education, 1(1) 70-75.

Oriafo, S. O. (1986) An Evaluation of Female Students' Achievement in Secondary School Science Implication for National Development. STAN Annual Conference, 161 - 169.

Osibodu, B. M. (1985). Girls Participation in Science, Mathematics and Technology in Nigeria, Problem and Regional Workshop Accra, Ghana.

Oyedokun, M. R. (2001). Female Participation in Science Subject Nigeria Colleges of Education. Implication for Science Education, STAN Annual Conference 161 - 164.

Roman, N. V (2011) Maturial parenting in single and perspectives. Journal of Social Behaviour and Personality, 39 (5), 577-586.

Roussanov N. \& Savor P. (2013) Marriage managers' attitudes to risk. Retrieved on $4^{\text {th }}$ June 2015 from http: //sites. Temple. Edu/ psawor/ files/2013/08/status-managers-draaft-2013-12-13.pdf.

Sarumi, L.M. (1990). An investigation into teacher student relationship selected secondary schools in Ayedade local government, Osun State. B.Ed Project. University of Ibadan.

Science Teachers Association Nigeria (1992) Women in STM, the Nigeria Experience. STAN Positive Paper No. 2.

Tamir, P. (1979) Effect of Teachers Background on Teaching and Student Achievement in Botany and Zoology Journal of Science Education 60, 3 July.

Titus, S. V. \&Annaraja, P. (2012) Relationship between metacognition and teaching competency of secondary teacher education students. New Horizons in educational research, 4(1)27-31.

Tyagi S. (2013) A Study of Teaching Effectiveness of secondary school Teachers in Relation to their Demographic Characteristics. International Journal of Engineering and Innovative Technology (IJEIT), 3 (1), 288-295.

Usman, K. O (2003) Influence of shortage of human resources on the effective instruction of Mathematics in Secondary Schools. Journal of WCCI Nigeria Chapter Forum, 4(2) 176-184

Wenginsky, H. (2002) How Schools Masters: The link Between Teacher Classroom Practice and Student Academic Performance Educational Analysis Archives 10, (1), 10 - 17.

Yilmaz H. \&Cavas P. H (2008) The Effect of the teaching Practice on Pre-service Elementary Teachers' Science Teaching Efficacy and classroom management Beliefs. Eurasia. Journal of Mathematics, Science and Technology Education, 4 (1) 45-54. 